SlavVaria 1/2021. 379-383

DOI: $10.15170 /$ SV.1/2021.379

\author{
CZUMFT RÉKA \\ (Budapest, Magyarország)
}

\title{
Új jelenség a kultúrában: kult-termékek
}

A Kult-termékek. Tömegkultúra napjaink Oroszországában: Világok konstruálása, sorozatok burjánzása címú tanulmánykötet ${ }^{1}$ egy 2008-ban életre hívott interdiszciplináris nemzetközi projekt legutóbbi konferenciájának anyagát adja közre „kollektív monográfia” formájában. A projekt keretein belül eddig hat tudományos konferencia került megrendezésre, melyek közül az utolsónak 2019-ben Hrodna város egyeteme adott otthont Belaruszban. A konferenciasorozat célja, hogy feltárja a kortárs orosz (és nem csak orosz) tömegirodalom/tömegkultúra múködését. A 2020-ban megjelent kötetben (felelős szerkesztő: T. Avtuhovics, tudományos szerkesztő: M. Abaseva, I. Szavkina, M. Csernyak) szereplő tanulmányok elsősorban a sorozat műfajára koncentrálnak, a sorozatok létrejöttének, terjedésének lehetőségeit vizsgálják és mutatják be, nem csak az irodalom és a vizuális műfajok keretein belül, hanem ezek kölcsönhatásában, illetve a számítógépes játékok területén is. A kötet öt fejezetben mutatja be az egyes kutatók munkáját, így kijelölve a konferencia öt fô irányvonalát.

Az első fejezet a sorozatosság (сериальность) jelenségének esztétikai és szociokulturális aspektusaival foglalkozik. G. Tulcsinszkij, a Setting, sorozatosság és igény a stabil gondolati világképre címú tanulmányában a sorozatosság és az ismétlés jelenségeit elsősorban mint az információ átadásának, elültetésének eszközeit vizsgálja a társadalmi diskurzus különböző színterein, például az orosz állami kommunikációban. A fejezet második tanulmányában O. Cvetkova a társadalom müködésének az ún. „képernyőkultúra” hatására zajló átalakulását járja körbe. A szerző abból a feltevésből indul ki, hogy a technológia befolyásolja az egyén világnézetét, ezen keresztül alakítva annak orientációs pontjait a társadalmon belül. Az ezt követő cikkben M. Zagidullina a sorozatok egy másik típusát vizsgálja a Black mirror anyagán, melyben az egyes részeket nem visszatérő szereplők kötik össze, hanem a környezet, a szüzsé egyes kapcsolódási pontjai teremtik meg az úgynevezett gyenge settinget, ami szükséges ahhoz, hogy a különálló részeket a befogadó összefüggő darabokként értelmezze. Bizonyos szempontból kapcsolódik ehhez a témához I. Szavkina tanulmánya is, hiszen az egyes adaptációk között is

\footnotetext{
${ }^{1}$ Культ-товары. Массовая культура в современной России: конструирование миров, умножение серий (отв. ред. Т. Е. Автухович; под науч. ред. М. П. Абашевой, И. Л. Савкиной, М. А. Черняк). Гродно: ГрГУ им. Янки Купалы, 2020. - 367 с.
} 
megfigyelhető a gyenge setting kialakulása. A szerző kitér arra, mi a különbség adaptáció és replikáció között, illetve az orosz Nyomozónő (Ищейка) sorozat példáján bemutatja az olvasó számára az eredeti mű és az adaptáció közötti kapcsolódási pontokat. A fejezet utolsó tanulmánya szintén az adaptáció jelenségéhez köthető. O. Turiseva egy adott (jelen esetben skandináv) sorozat különböző országokban készített adaptációinak különbségeit elemzi munkájában. A szerző rámutat arra, hogyan alakul át a kiinduló szüzsé a befogadó kultúrától függően: átalakul a tettes és az áldozat kapcsolata, megváltozik a motiváció, a konkrét gyilkosság helyett annak pszichológiai oldala kerül előtérbe az orosz, az amerikai és a francia feldolgozásban.

A kötet második fejezete $A$ világképtől a játékuniverzumig címet viseli. A fejezet elsősorban a számítógépes játékkal mint a tömegkultúra új termékével és annak kulturális funkciójával foglalkozó tanulmányokat mutat be. Az egyes munkák közös pontja az a megállapítás, hogy a 21. században a számítógépes játékok épp olyan fontos tömegkulturális jelenséggé váltak, mint a tömegirodalom és a fanfiction-ök.

A fejezet első tanulmánya a STALKER-jelenséget igyekszik bemutatni. A szerzőpáros, V. Abasev és M. Abaseva a S.T.A.L.K.E.R. nevű számítógépes játék és STALKER/CTAЛKEP című irodalmi müvek univerzum-alakítását tárgyalja. Ennek érdekessége nem csak a számítógépes játék és irodalom összekapcsolódásában rejlik, hanem abban is, hogy a könyveket, szövegeket és játékokat több különböző szerző hozta létre, így azok egy igen tág univerzumot alkotnak. A második tanulmány, melynek szerzője Ja. Szoldatkina, az irodalom és más, egy adott univerzumhoz tartozó elemek kapcsolatát emeli ki. A Westeros geopoétikája címú írás az irodalom és az irodalmon kívüli vizuális anyag, jelen esetben térképek és internetes stream szolgáltatók által készített megfilmesítések kapcsolatát és együttes univerzumépítési lehetőségeit veszi górcső alá. Az ezt követő tanulmány, a Történelem a történelmen keresztül: a Tobol, mint transzmediális projekt (A. Bulgakova) a sorozatot mint a brandépítés egyik eszközét mutatja be az orosz Tobol címü, történelmi tényeken alapuló, de fikciós sorozat anyagát feldolgozva. A Tobol kulturális projekten belül elválasztható irodalmi és vizuális összetevő, mivel a Tobol megalkotóinak nem titkolt célja volt Szibéria „reklámozása” a projekten keresztül. A fejezet utolsó tanulmánya megfordítja az eddigi nézőpontot, és egy valós történelmi időszakhoz kapcsolódó kulturális univerzumteremtést vizsgál, négy orosz sorozat anyagán. A. Fokin tanulmánya az olvadás koráról 2010 után forgatott orosz sorozatokat elemez. Munkájának célja bemutatni azt, hogy a négy sorozat olvadás-univerzuma hogyan befolyásolja azon befogadók „olvadás-nézőpontját”, akik maguk nem éltek az adott korszakban.

A harmadik fejezet a Határok átlépése - múfaji kísérletek címet viseli, fő témája a müfaji keveredés és annak lehetőségei. Az első tanulmány a sorozat és a bouts-rimés regény közötti kapcsolatot tárja fel, illetve rámutat arra, hogyan vált az internet az újkori bouts-rimés regények fő platformjává. A szerző, M. Csernyak amellett érvel, hogy napjaink sorozata múfajilag a bouts-rimé regénnyel 
áll összefüggésben. A második tanulmány a televíziókból jól ismert szituációs komédiák és az irodalom lehetséges összekapcsolódását elemzi. A szerző, A. Zezjulevics elsősorban az Így jártam anyátokkal és az Agymenók címú sorozatokból kiindulva mutat rá azokra a párhuzamos pontokra Szasa Szotnyik Reklamist címü regényében, amelyek lehetővé teszik, hogy az alapvetően televíziós müfaj leképződhessen egy irodalmi mű keretein belül. Az ezt követő munka szerzője, L. Nyemcsenko azt a folyamatot igyekszik áttekinteni, melynek eredményeként egyre több, korábban kizárólag mozifilmet rendező szakember jut el egy-egy sorozat rendezői székébe. A jelenség egyik okaként a sorozat múfajának átértékelődését nevezi meg a szerző. Az ezt követő írás Jean-Francois Laguionie A festmény címú animációs filmjét elemzi. A tanulmány szerzője, E. Abramovszkih abból indul ki, hogy a mozifilm és az irodalmi mú narratívája egybevethető, köztük párhuzamok tárhatóak fel, azonban a mozinyelvre a sorozatosság jelenségének sajátos múködése jellemző. A következő cikkben a szerző, O. Grinyevics az orosz irodalom „(nemesi) udvarházi szövegének” (усадебный текст) megjelenését és műfaji kérdéseit mutatja be az orosz kortárs irodalomban. Az orosz irodalom „udvarházi szövegének” érdekessége, hogy napjainkban nemcsak a tömegkultúrában, de a magasirodalomban is újra megjelenik, különböző funkcióval. A fejezet utolsó tanulmánya egy éppen aktuális jelenséget, a COVID-drámákat tekinti át. A. Lepiseva a COVID-drámák szerkezeti és narrációs elemeit elemzi, kitérve a szerző és befogadó közötti szerves kapcsolatra. Megállapítja, hogy az egész világon végigsöprő leállás miatt a COVID-drámák elsődleges terévé az online tér vált.

A kötet negyedik fejezetének címe Sorozatok, világok, és a „részvétel kultúrája”. Az első cikk D. Colombo munkája, melyben bemutatja azt a folyamatot, amint az egyes irodalmi hősök (például Sherlock Holmes) elszakadva eredeti irodalmi gyökereiktől, önálló, „népi” irodalmi hőssé válnak. A második tanulmányban T. Avtuhovics a híres Metro-univerzum lezárásának lehetséges okait tárgyalja. Munkájában több okot is megnevez, amely a sikeres Metro-projekt váratlan lezárását okozhatta: ezek, többek között, a kiadó hozzáállása, Gluhovszkij szerzői munkájának átalakulása és az olvasói igényektől való eltávolodás. Ezt követően Ju. Buldakova egy másik irányból tekinti át az olvasó és szöveg közötti viszonyt. Tanulmánya az ún. fanfiction-ök müfaji kérdéseivel foglalkozik, elválasztva egymástól az egyes formákat aszerint, hogy azok elemzik, magyarázzák vagy bővítik egy adott univerzum történéseit. Szintén a fanfiction jelenségét elemzi a következő tanulmány. A társszerzők, A. Nyizsnyik és M. Hazanova Fanfiction mint komplex médiajelenség címú tanulmánya feltárja a fanfiction és a professzionális kultúraipar kapcsolatát, illetve rámutat arra, hogy az internet megjelenése és elterjedése egészen új dimenzióba helyezte a fanfiction-t, lehetővé téve kapcsolódását nem csak irodalmi múvekhez, de filmekhez, számítógépes játékokhoz is. A fejezet zárótanulmánya S. Falalejeva munkája, mely a Hamupipőke archetípus 21. századi változatait mutatja be. A tanulmány abból 
indul ki, hogy a tömegirodalom aktívan használja a folklór- és a szerzői varázsmesék szüzséit. A szerző V. Propp elméletét felhasználva mutatja ki, hogyan jelenik meg a Hamupipőke archetípus a vizsgált női szerzők regényeiben, és kitér azokra a „kötelező” narratív elemekre, amelyek minden esetben megjelennek ezekben a művekben, illetve a transzformációs pontokra is.

Az ötödik, egyben zárófejezet címe Média: szélesedő világmindenség, fő témája az internet, mint a (tömeg)kultúra és a sorozat tere, de szóba kerülnek a 21. század más nyelvhasználati stratégiái, jelrendszerei is. A fejezet első tanulmányának szerzője V. Konsztancsuk munkájában a sorozatosság (серийность) és az internet kapcsolatát vizsgálja. A cikk a tömegkultúra esztétikájának alapjaként az ismétlődést jelöli meg, amelyet az online videómegosztók tesznek lehetővé: egy adott videó korlátlan alkalommal tekinthető meg. Annak következtében, hogy a befogadó nincs időhöz kötve, mint a televízió esetén, a médiafogyasztási szokások is átalakultak Konsztancsuk szerint. A második tanulmány a főzőshowk és a sorozatosság kapcsolatát tekinti át. E. Sesztakova abból indul ki A sorozatosság természete, struktúrája és funkciója a kulináris reality müsorokban címú munkájában, hogy a főzőműsorok sorozatossága sajátos, és már nem az ételelkészítés folyamatára koncentrál elsősorban, hanem az elkészítés és elfogyasztás körülményeire. Ennek eredményeként napjainkban a főzőshowk is tematizálódnak, és egyes műsorvezetők köré komoly brand épül. A harmadik cikkben M. Kosztyuhina a könyv és más médiafelületek kapcsolatát vizsgálja a népszerű Aludttejfalva (Prosztokvasino) rajzfilmsorozatot elemezve. A szerző azt a folyamatot elemzi, ahogyan a gyermekek a népszerű szovjet mesesorozat egyes figuráival a 21. századi kommunikációs és médiafelületeken keresztül kerülnek kapcsolatba. A vizsgálat során bizonyítást nyert, hogy a gyermekek már elsősorban a vizuális formákból és az népszerủ tejtermék márkaneveként ismerik a rajzfilmet, és csak később olvasnak arról az alakról, akit már ismernek. A Prosztokvasino-jelenség ma már szinte a teljes kulturális univerzumot lefedi: könyvek, mesefilmek, képregények, színezők is kapcsolódnak hozzá, melyekkel aktívan működik együtt a márkanév. Az utolsó előtti tanulmány M. Stukkert cikke, amely szinten V. Propp elméletére támaszkodva elemzi a Parafenomének harca című műsor belső szerkezetét. A cikk feltárja azokat a belső pontokat, amelyek összekötik az egyes évadokat, ezek mellett rámutat arra a folyamatra, melynek során az egyes szereplők saját médiafelülethez jutnak az interneten. A kötet utolsó tanulmánya D. Karpov és E. Vasziljeva közös munkája, témája pedig napjaink két orosz rap előadójának, Jubilej és LSzP albumainak sorozatossága. A szerzők véleménye szerint a két előadó a sorozatosság kétféle módját követve állítja össze albumait. Ez a két albumösszeállítási mód egybeesik a ciklizáció két aktuális modelljével: az első modell az egy cikluson belüli belső kapcsolatok létrehozásának eredményeként, paratextusok segítségével köti össze a ciklus egyes darabjait. A második modell egy horizontális szüzsé létrehozására törekszik, amely 
nemcsak egy ciklus egyes darabjait kapcsolja egymáshoz, de ciklusokon átívelve akár egy egész életművet egybeköt. Utóbbira példaként LSzP egyik albumsorozatát hozza fel a szerzőpáros: az egyes albumok önálló címmel rendelkeznek, de mindegyik kapcsolódik a város képéhez.

A kötet szerzői egységesen arra jutnak, hogy a sorozatosság a tömegkultúra minden jelenségét érinti, legyen szó vizuális vagy verbális müfajról. Az egyes tanulmányok közös alapja a tömegkultúra és az online tér összekapcsolódása: ma már nem csak a vizuális múfajok, hanem az irodalom is egyre inkább az internethez kapcsolódik. A szerzők a tömegkultúra és az internet összefonódását több szempontból is elemzik a kötetben: a befogadó nézőpontjából, a tömegkultúra és az univerzumépítés kapcsolatának szemszögéből, illetve a különböző formák (például vizuális és irodalmi) egymáshoz való viszonyát is bemutatják. Ezek mellett rámutatnak arra is, milyen hatással van az egyén médiafogyasztási szokásaira az, hogy az egyes tömegkulturális jelenségek hozzáférési helyévé az online tér vált. 